University of Nebraska - Lincoln

DigitalCommons@University of Nebraska - Lincoln

Downflow Limestone Beds for Treatment of Net-Acidic, Oxic, IronLaden Drainage from a Flooded Anthracite Mine, Pennsylvania, USA: 2. Laboratory Evaluation

\author{
Charles A. Cravotta III \\ US Geological Survey, PA Water Science Center, 215 Limekiln Rd, New Cumberland, PA, USA, \\ cravotta@usgs.gov \\ Suzanne J. Ward \\ USGS PA Water Science Center, New Cumberland, PA 17070, USA \\ Jane M. Hammarstrom \\ USGS Eastern Mineral Resources Program, Reston, VA 20191, USA
}

Follow this and additional works at: https://digitalcommons.unl.edu/usgsstaffpub

Part of the Earth Sciences Commons

Cravotta, Charles A. III; Ward, Suzanne J.; and Hammarstrom, Jane M., "Downflow Limestone Beds for Treatment of Net-Acidic, Oxic, Iron-Laden Drainage from a Flooded Anthracite Mine, Pennsylvania, USA: 2. Laboratory Evaluation" (2008). USGS Staff -- Published Research. 331.

https://digitalcommons.unl.edu/usgsstaffpub/331

This Article is brought to you for free and open access by the US Geological Survey at DigitalCommons@University of Nebraska - Lincoln. It has been accepted for inclusion in USGS Staff -- Published Research by an authorized administrator of DigitalCommons@University of Nebraska - Lincoln. 


\title{
Downflow Limestone Beds for Treatment of Net-Acidic, Oxic, Iron-Laden Drainage from a Flooded Anthracite Mine, Pennsylvania, USA: 2. Laboratory Evaluation
}

\author{
Charles A. Cravotta III · Suzanne J. Ward · \\ Jane M. Hammarstrom
}

Received: 10 July 2007 / Accepted: 26 December 2007/Published online: 12 February 2008

(C) Springer-Verlag 2008

\begin{abstract}
Acidic mine drainage (AMD) containing elevated concentrations of dissolved iron and other metals can be neutralized to varying degrees by reactions with limestone in passive treatment systems. We evaluated the chemical and mineralogical characteristics and the effectiveness of calcitic and dolomitic limestone for the neutralization of net-acidic, oxic, iron-laden AMD from a flooded anthracite mine. The calcitic limestone, with $\mathrm{CaCO}_{3}$ and $\mathrm{MgCO}_{3}$ contents of 99.8 and $<0.1 \mathrm{wt} \%$, respectively, and the dolomitic limestone, with $\mathrm{CaCO}_{3}$ and $\mathrm{MgCO}_{3}$ contents of 60.3 and $40.2 \mathrm{wt} \%$, were used to construct a downflow treatment system in 2003 at the Bell Mine, a large source of AMD and baseflow to the Schuylkill River in the Southern Anthracite Coalfield, in east-central Pennsylvania. In the winter of 2002-2003, laboratory neutralization-rate experiments evaluated the evolution of effluent quality during 2 weeks of continuous contact between AMD from the Bell Mine and the crushed calcitic or dolomitic limestone in closed, collapsible containers (cubitainers). The cubitainer tests showed that: (1) net-alkaline effluent could be achieved with detention times greater than $3 \mathrm{~h}$, (2) effluent alkalinities and associated dissolution rates were equivalent for uncoated and $\mathrm{Fe}(\mathrm{OH})_{3}$-coated calcitic limestone, and (3) effluent alkalinities and associated dissolution rates for dolomitic limestone were about half those for calcitic limestone. The dissolution rate data for the cubitainer tests were used with
\end{abstract}

C. A. Cravotta III $(\bowtie) \cdot$ S. J. Ward

USGS PA Water Science Center, New Cumberland,

PA 17070, USA

e-mail: cravotta@usgs.gov

J. M. Hammarstrom

USGS Eastern Mineral Resources Program, Reston,

VA 20191, USA data on the volume of effuent and surface area of limestone in the treatment system at the Bell Mine to evaluate the water-quality data for the first 1.5 years of operation of the treatment system. These rate models supported the interpretation of field results and indicated that treatment benefits were derived mainly from the dissolution of calcitic limestone, despite a greater quantity of dolomitic limestone within the treatment system. The dissolution-rate models were extrapolated on a decadal scale to indicate the expected decreases in the mass of limestone and associated alkalinities resulting from the long-term reaction of AMD with the treatment substrate. The models indicated the calcitic limestone would need to be replenished approaching the 5-year anniversary of treatment operations to maintain net-alkaline effluent quality.

Keywords Coal mine drainage - Cubitainer tests . Dolomite $\cdot$ Kinetics modelling $\cdot$ Limestone .

Passive treatment

\section{Introduction}

Background

Various strategies to remove dissolved iron, aluminum, manganese, and associated metals from acidic mine drainage (AMD) could be appropriate depending on the volume of the mine discharge, its alkalinity and acidity balance, the concentrations of various metal species, and the available resources for construction and maintenance of a treatment system (e.g. Hedin et al. 1994; PIRAMID Consortium 2003; Skousen et al. 1998; Watzlaf et al. 2004). For the passive treatment of net-acidic AMD (acidity $>$ alkalinity; hot acidity $>0$ ), the effluent typically is routed through a 
packed bed of crushed limestone or mixtures of organic-rich materials and limestone, wherein the effluent is neutralized and acquires alkalinity. If net alkaline, effluent with nearneutral $\mathrm{pH}$ (6 to 8 ) would be maintained after the oxidation and hydrolysis of dissolved iron, manganese, and associated metals; however, if net acidic, the effluent $\mathrm{pH}$ ultimately could decline to acidic values $(<4.5)$ (Kirby and Cravotta $2005 \mathrm{a}, \mathrm{b})$. Considering near-neutral $\mathrm{pH}$ and iron removal as goals, treatment effectiveness will depend on the relative rates of alkalinity production, iron oxidation, and solidsremoval processes. Nevertheless, limestone-dissolution rates (e.g. Morse 1983; Plummer et al. 1979) and iron-oxidation rates (e.g. Kirby et al. 1999) can vary by orders of magnitude depending on environmental conditions such as temperature, $\mathrm{pH}$, surface area of reactive substrate, concentrations of dissolved and suspended constituents, and the possible involvement of microorganisms in chemical reactions. Consequently, AMD passive-treatment guidelines generally are insufficient to determine an optimum treatment strategy because of dynamic variations in environmental conditions and uncertain relations between treatment-system size and the removal of acidity and other pollutants.

The dissolution of calcite $\left(\mathrm{CaCO}_{3}\right)$ and dolomite $\left(\mathrm{CaMg}\left(\mathrm{CO}_{3}\right)_{2}\right)$, which are the principal minerals in limestone, increases the $\mathrm{pH}$, alkalinity $\left(\mathrm{HCO}_{3}{ }^{-}+\mathrm{CO}_{3}{ }^{2-}+\right.$ $\mathrm{OH}^{-}$), and concentrations of calcium $(\mathrm{Ca})$ and magnesium $(\mathrm{Mg})$ in a contacting solution by the following reactions or some combination thereof:

$$
\begin{aligned}
& \mathrm{CaCO}_{3}(\mathrm{~s})+2 \mathrm{H}^{+} \leftrightarrow \mathrm{Ca}^{2+}+\mathrm{H}_{2} \mathrm{CO}_{3}^{*} \\
& \mathrm{CaCO}_{3}(\mathrm{~s})+\mathrm{H}_{2} \mathrm{CO}_{3}^{*} \leftrightarrow \mathrm{Ca}^{2+}+2 \mathrm{HCO}_{3}^{-} \\
& \mathrm{CaMg}\left(\mathrm{CO}_{3}\right)_{2}(\mathrm{~s})+4 \mathrm{H}^{+} \leftrightarrow \mathrm{Ca}^{2+}+\mathrm{Mg}^{2+}+2 \mathrm{H}_{2} \mathrm{CO}_{3}^{*} \\
& \mathrm{CaMg}\left(\mathrm{CO}_{3}\right)_{2}(\mathrm{~s})+2 \mathrm{H}_{2} \mathrm{CO}_{3}^{*} \leftrightarrow \mathrm{Ca}^{2+}+\mathrm{Mg}^{2+}+4 \mathrm{HCO}_{3}^{-}
\end{aligned}
$$

$\mathrm{HCO}_{3}^{-}+\mathrm{H}^{+} \leftrightarrow \mathrm{H}_{2} \mathrm{CO}_{3}^{*} \leftrightarrow \mathrm{H}_{2} \mathrm{O}+\mathrm{CO}_{2}(\mathrm{~g})$

where $\left[\mathrm{H}_{2} \mathrm{CO}_{3}{ }^{*}\right]=\left[\mathrm{CO}_{2}(\mathrm{aq})\right]+\left[\mathrm{H}_{2} \mathrm{CO}_{3}{ }^{\mathrm{o}}\right]$ (Plummer et al. 1979; Stumm and Morgan 1996). Hence, the stoichiometric dissolution of $1 \mathrm{mmol} \mathrm{CaCO}_{3}$ will produce $1 \mathrm{mmol} \mathrm{Ca}{ }^{2+}$; the stoichiometric dissolution of $1 \mathrm{mmol}$ $\mathrm{CaMg}\left(\mathrm{CO}_{3}\right)_{2}$ will produce $1 \mathrm{mmol} \mathrm{Ca}^{2+}$ and $1 \mathrm{mmol}$ $\mathrm{Mg}^{2+}$; and the $\mathrm{HCO}_{3}{ }^{-}$produced by Eqs. 2 through 4 can neutralize acid $\left(\mathrm{H}^{+}\right)$and increase $\mathrm{pH}$ by Eq. 5. Because combinations of the above reactions can produce $\mathrm{H}_{2} \mathrm{CO}_{3}$ *, $\mathrm{HCO}_{3}{ }^{-}$, and/or $\mathrm{CO}_{2}(\mathrm{~g})$, the stoichiometric quantities of $\mathrm{HCO}_{3}{ }^{-}$produced by limestone dissolution can vary from 0 to $2 \mathrm{mmol} / \mathrm{mmol} \mathrm{CaCO}_{3}$ or $4 \mathrm{mmol} / \mathrm{mmol} \mathrm{CaMg}\left(\mathrm{CO}_{3}\right)_{2}$.

Continuous inundation and retention of carbon dioxide $\left(\mathrm{CO}_{2}\right)$ can enhance limestone dissolution and alkalinity production because the rate and extent of limestone dissolution tend to increase with increased partial pressure of
$\mathrm{CO}_{2}\left(P_{\mathrm{CO}_{2}}\right)$ (Eqs. 2, 4) and/or decreased pH (Eqs. 1, 3) (Langmuir 1997; Plummer et al. 1979; Stumm and Morgan 1996). Furthermore, the apparent dissolution rate tends to increase as the exposed surface area of limestone increases (particle size decreases) and/or the volume of solution increases (Morse 1983). Although the dissolution rate of calcite tends to be faster than that of dolomite under typical environmental conditions (Herman and White 1985; Langmuir 1997), some researchers have suggested that dolomite may be preferable to calcite for neutralization of low-pH, sulfuricacid solutions because of the potential for gypsum $\left(\mathrm{CaSO}_{4} \cdot 2 \mathrm{H}_{2} \mathrm{O}\right)$ coatings to form on calcite (e.g. Huminicki and Rimstidt 2007). Because of locally elevated concentrations of $\mathrm{Ca}^{2+}$ and other reaction products near the surface of calcite, the potential for gypsum formation on the calcite surface could be greater than indicated by the saturation index based on the measured calcium and sulfate concentrations in the bulk solution (e.g. Ball and Nordstrom 1991; Stumm and Morgan 1996). Nevertheless, few studies have evaluated dolomite for the neutralization of AMD. Of note, Watzlaf and Hedin (1993) evaluated the reaction between $\mathrm{AMD}$ and different samples of limestone with variable $\mathrm{CaCO}_{3}$ and $\mathrm{MgCO}_{3}$ contents in closed, collapsible containers (cubitainer $\AA$, Hedwin Corporation 2007) over 11 days. The alkalinity generated by dolomitic limestone containing $46 \mathrm{wt} \% \mathrm{CaCO}_{3}$ was approximately half of that produced by reaction of the same AMD with calcitic limestone samples containing 91 to 99 wt\% $\mathrm{CaCO}_{3}$. Consequently, Hedin et al. (1994) and Watzlaf et al. (2004) specified crushed limestone fragments with a maximum diameter of $5 \mathrm{~cm}$ and a minimum $\mathrm{CaCO}_{3}$ content of $90 \%$ for use in AMD passive-treatment systems.

Criteria for determining the size of a limestone bed for the passive treatment of AMD typically consider the flow rate and the alkalinity and acidity of the influent. Hedin and Watzlaf (1994), Hedin et al. (1994), and Watzlaf et al. (2004) used the average flow rate and assumed a constant alkalinity, approaching the concentration in equilibrium with $\mathrm{CaCO}_{3}$, to estimate the quantity of limestone needed for an anoxic limestone drain (ALD). This widely used sizing method prescribes detention times of $15 \mathrm{~h}$ or more over a 20-year life span and is warranted for AMD with elevated acidity (>300 mg/L). However, shorter detention times and lower alkalinities may be warranted for AMD that has a low acidity, a large flow rate, and/or where space for construction is limited. In such cases, an appropriate size can be determined by evaluating the rate of reaction between the limestone and the AMD and the corresponding alkalinity concentrations for a range of detention times. Building on early methods of Watzlaf and Hedin (1993), Cravotta (2003) developed asymptotic rate models to describe the alkalinity concentration as a function of contact time (detention time) between the AMD and limestone 
in cubitainers and in corresponding ALD systems. Cravotta suggested these rate models could be used to estimate the minimum initial mass of limestone needed for an ALD to produce alkalinity greater than or equal to the influent acidity over a specified life span. Cravotta et al. (2004) applied the cubitainer testing and modeling methods to evaluate the effects of thin coatings of $\mathrm{Fe}(\mathrm{OH})_{3}$ or $\mathrm{Al}(\mathrm{OH})_{3}$ on the rate of limestone dissolution in an ALD or an oxic limestone drain (OLD). They concluded that with the additional consideration of surface-area corrections, the cubitainer testing and modeling methods could be applicable to the design and evaluation of a variety of limestone-based passive treatment systems, such as downflow or upflow systems that attempt to manage the accumulation of secondary solids within the limestone bed.

The precipitation and accumulation of $\mathrm{Fe}(\mathrm{OH})_{3}, \mathrm{Al}(\mathrm{OH})_{3}$, gypsum, and various other secondary solids within a limestone-based treatment system can "armor" the limestone surfaces, potentially decreasing the rate and extent of limestone dissolution and alkalinity production, and can decrease the porosity and permeability of the limestone bed (Cravotta and Trahan 1999; Cravotta and Watzlaf 2002; Hammarstrom et al. 2003; Hedin and Watzlaf 1994; Robbins et al. 1996, 1999; Watzlaf et al. 2000; Weaver et al. 2004). Hence, widely used design criteria for ALDs (e.g. Hedin et al. 1994; PIRAMID Consortium 2003; Watzlaf et al. 2004) generally are conservative with respect to the permissible concentrations of dissolved $\mathrm{O}_{2}, \mathrm{Fe}^{\mathrm{III}}$, and $\mathrm{Al}$ in influent $\left(<1 \mathrm{mg} / \mathrm{L} \mathrm{O}_{2}\right.$, $\mathrm{Fe}^{\mathrm{III}}$, or $\left.\mathrm{Al}\right)$. Nevertheless, short-term laboratory studies $(<2$ years) have indicated that under some circumstances, thinly armored limestone can be effective for neutralization of mine water containing moderate concentrations of dissolved $\mathrm{O}_{2}$ and low to moderate concentrations of $\mathrm{Fe}^{\mathrm{III}}$ and $\mathrm{Al}(<10 \mathrm{mg} / \mathrm{L})$ (Cravotta et al. 2004; Sterner et al. 1998; Watzlaf 1997). Perforated piping can be installed within or beneath the limestone bed to facilitate the flushing of accumulated precipitates (Schueck et al. 2004; Weaver et al. 2004). Thus, it was hypothesized that a downflow limestone bed with flushing pipes could be effective for treatment of net-acidic, oxic AMD with low to moderate concentrations of dissolved metals and that laboratory cubitainer tests could indicate the potential effects of armoring of the limestone and associated performance of the treatment system.

\section{Purpose and Scope}

This paper describes laboratory dissolution-rate experiments and computational methods to evaluate reactions between net-acidic, oxic, iron-bearing AMD and limestone of different compositions. The methods could be useful for the evaluation of various substrates for treatment of acidic effluents from mines and other sources. Laboratory neutralization-rate experiments that were conducted by the US Geological Survey (USGS) in March 2002 and December 2003 with $\mathrm{Fe}(\mathrm{OH})_{3}$-coated calcitic limestone, uncoated calcitic limestone, and uncoated dolomitic limestone indicated the relations between detention time, $\mathrm{pH}$, and alkalinity of effluent and possible differences in reaction rates among the different substrates. In this paper, the laboratory data were used to develop asymptotic first-order and second-order models to indicate the rates of dissolution of calcitic limestone and dolomitic limestone by the acidic effluent, to quantify potential effects of metal-rich coatings on reaction rates, and to evaluate the performance of a fieldscale passive-treatment system constructed of these materials at the Bell Mine Discharge in eastern Pennsylvania.

\section{Description of Study Area}

Detailed descriptions of the Bell Mine Discharge treatment system and associated monitoring data for the first 1.5 years of its performance (April 2004-October 2005) are reported in a companion paper (Cravotta and Ward 2008). In summary, a passive-treatment system with two parallel, downflow cells, $\mathrm{A}$ and $\mathrm{B}$, each filled with 300 metric tons ( $t$ ) of calcitic limestone of "R-4" size (8$30 \mathrm{~cm}$ ) and 1,090 t dolomitic limestone of "R-5" size (13$45 \mathrm{~cm}$ ) was constructed at the Bell Mine Discharge and was flooded continuously with AMD influent to a depth of $0.65 \mathrm{~m}$ in March 2004. Each of the two downflow cells treated approximately half of the influent to the treatment system and was equipped with separate underdrain networks, outflow pipes, and spillways. Effluent that was not transmitted downward through the treatment beds to the outflow pipes exited by the spillways. Although a $0.3 \mathrm{~m}$ thick layer of organic-rich compost was added to the calcitic limestone bed in cell $\mathrm{B}$, a geotextile liner placed between the compost and the underlying dolomitic limestone promoted the overflow and short-circuiting of flow around the sides cell B. The combined flows from the outlet pipes and spillways from both downflow-limestone cells A and B were collected into an aerobic settling pond and wetland where final oxidation, precipitation, and settling of metal-rich particles would occur. This paper focuses on neutralization reactions within the limestone beds of the treatment system at the Bell Mine.

\section{Materials and Methods}

Limestone Sampling and Analysis

In order to characterize the physical and chemical characteristics that may affect reaction rates with AMD, 
limestone samples used to construct the Bell Discharge treatment system (Cravotta and Ward 2008) and for laboratory dissolution-rate experiments (described below) were obtained from stockpiles at commercial sources in Lebanon and Lancaster Counties, Pennsylvania. High-purity calcitic limestone was obtained from the Annville Quarry, near Annville, Lebanon County. According to O'Neill (1964, pp. 5 and 30, sample 393), this quarry is in the Middle Ordovician Annville Limestone, which has average $\mathrm{CaCO}_{3}$ content of $98.5 \mathrm{wt} \%$ and $\mathrm{MgCO}_{3}$ content of $1.1 \mathrm{wt} \%$. Another sample of limestone was obtained from the Burkholder Quarry, near Ephrata, Lancaster County. Limestone from the Burkholder Quarry is in the undivided Lower Ordovician Beekmantown Group and is predominantly dolomitic with average $\mathrm{CaCO}_{3}$ content of $64.8 \mathrm{wt} \%$ and $\mathrm{MgCO}_{3}$ content of $32.2 \mathrm{wt} \%$ (O'Neill 1964, pp. 4 and 25, sample 309). According to the Martin Limestone Co. (written commun. 2004) and O'Neill (1964, pp. 25, samples 313 and 314), the Beekmantown Group locally contains high-purity limestone with $\mathrm{CaCO}_{3}$ content greater than or equal to $93.5 \mathrm{wt} \%$.

To determine mineral composition, subsamples of the calcitic limestone and dolomitic limestone were pulverized and analyzed by X-ray diffraction (XRD) at the USGS Minerals Resources laboratory in Reston, Virginia (Taggart 2002). The XRD patterns were collected on a Scintag thetatheta diffractometer using copper radiation over the range of $3^{\circ}-70^{\circ}$ with a $0.02^{\circ}$ step size and a count time of one second per step. XRD patterns were interpreted with the aid of Scintag and MDI Applications JADE search/match software and compared with reference patterns in the Powder Diffraction File (ICDD 2002). The relative amounts of different minerals were estimated by quantitative phase analysis using the Siroquant computer program (Taylor and Clapp 1992). Siroquant utilizes the full XRD profile in a Rietveld refinement to estimate the weight percentages of different minerals in a mixture (rock), based on a rigorous identification of minerals present prior to the refinement.

The average stone density and unit surface area of the calcitic and dolomitic limestone samples were determined at the USGS Water Science Center laboratory in New Cumberland, Pennsylvania, on the basis of the measured dimensions, weight, and volume of 50 particles of each rock type that had been sieved to retain Pennsylvania aggregate size "2NS" $(1.3-3.8 \mathrm{~cm})$ (Pennsylvania Department of Environmental Protection 2000). For each rock type, the average stone density of the 50 particles was computed from their combined weight and the volume of water displaced by these particles. Additionally, for each particle, the weight and the long, short, and intermediate axis lengths $\left(L_{1}, L_{\mathrm{s}}\right.$, and $L_{\mathrm{i}}$, respectively) were measured with a laboratory balance and calipers. Given the particle dimensions, weight $(M)$, and density $\left(\rho_{\mathrm{S}}\right)$, the unit surface area $\left(A_{\mathrm{S}}\right)$ of each particle was computed assuming an ellipsoidal sphere as the particle geometry (Santomartino 2004; Santomartino and Webb 2007). The surface area of an ellipsoid sphere $\left(A_{\mathrm{E}}\right)$, which is intermediate between that of a sphere and a rectangular prism with the same average diameter, was computed as:

$A_{\mathrm{E}}=\left(\pi \cdot D^{2}\right) / S$,

where

$D=2 \cdot\left(V_{\mathrm{S}} /(4 / 3 \pi)\right)^{1 / 3}$,

$S=1.15-0.25 \cdot L_{1} / D$,

and

$V_{\mathrm{S}}=M / \rho_{\mathrm{s}}$.

The actual particle volume $\left(V_{\mathrm{S}}\right)$ for the sieved particles ranged from 30 to $90 \%$ of the computed volume, assuming a rectangular prism as the particle geometry, with median and average values of $60 \%$. Hence, for various standard aggregate sizes, the particle volume could be assumed to be $60 \%$ of the rectangular prism volume:

$V_{\mathrm{S}}=0.6 \cdot\left(2 \cdot\left(\left(L_{\mathrm{l}} \cdot L_{\mathrm{s}}\right)+\left(L_{\mathrm{l}} \cdot L_{\mathrm{i}}\right)+\left(L_{\mathrm{s}} \cdot L_{\mathrm{i}}\right)\right)\right.$.

Accordingly, given the reported dimensions for standard aggregate sizes (Pennsylvania Dept of Environmental Protection 2000), the approximate unit surface area for different standard sizes of aggregate, including R-4 $(8-30 \mathrm{~cm})$ and R-5 $(13-45 \mathrm{~cm})$ used in construction of the treatment system, could be estimated using Eqs. 6, 7, 8, and 10.

\section{Laboratory Neutralization-Rate Experiments}

Laboratory neutralization-rate experiments were conducted in the USGS Water Science Center laboratory in New Cumberland, Pennsylvania, to evaluate the effects of detention time, limestone purity, and "armoring" by secondary mineral encrustations on limestone dissolution rate. Following methods of Cravotta (2003), the experiments documented the chemical evolution of AMD from the Bell Discharge in continuous contact with $2 \mathrm{~kg}$ of limestone for an elapsed time of 2 weeks in an enclosed, $3.8 \mathrm{~L}$ nominal volume cubitainer. Because the effluent in the cubitainer was recirculated with a peristaltic pump, the tests mimic chemical kinetics along the length of a simple plug-flow system (Cravotta 2003).

Before loading in cubitainers, crushed limestone was sieved to retain fragments with nominal diameters ranging from 0.5 to 1.5 inches (1.3 to $3.8 \mathrm{~cm}$ ), equivalent to Pennsylvania aggregate size "2NS" (1.3-3.8 cm) (Pennsylvania Dept of Environmental Protection 2000). The sieved limestone was washed with $5 \%$ (by volume) hydrochloric acid $(\mathrm{HCl})$, rinsed thoroughly with tap water 
and deionized water, and then air dried. Two sets of tests were conducted beginning March 11, 2002, and December 23, 2003. During the first set of tests in March 2002, two cubitainers contained clean, calcitic limestone and two others contained $\mathrm{Fe}(\mathrm{OH})_{3}$-coated calcitic limestone that had become thinly encrusted $(\approx 1 \mathrm{~mm})$ with precipitate after being immersed for 6 weeks at the Bell Discharge. During the second set of tests, one cubitainer contained uncoated calcitic limestone, a second contained previously tested $\mathrm{Fe}(\mathrm{OH})_{3}$-coated calcitic limestone, and the third and fourth contained clean, uncoated dolomitic limestone.

Immediately before each test, approximately $25 \mathrm{~L}$ of untreated AMD from the Bell Discharge was collected into four empty cubitainers, sealed without headspace, and transferred on ice to the laboratory. Within $2 \mathrm{~h}$ of collection, the influent was used to fill four other cubitainers containing $2 \mathrm{~kg}$ of limestone fragments. A peristaltic pump with four heads on a single shaft was connected to these four cubitainers for simultaneous circulation of solutions without the introduction of air (closed conditions). The pumping rate was maintained at 10 to $30 \mathrm{~L} / \mathrm{h}$ to minimize stratification and simulate flow through a bed of crushed limestone. The approximate field temperature of 9 to $11^{\circ} \mathrm{C}$ was maintained using an ice bath during the first $6 \mathrm{~h}$. After the first $6 \mathrm{~h}$ of the tests, the cubitainers and pump were placed in a refrigerator and maintained at $5^{\circ} \mathrm{C}$. Samples were collected at $0.5 \mathrm{~h}$ intervals during the first $6 \mathrm{~h}$, then at $24 \mathrm{~h}$, and less frequent intervals after the first day; the last sample was collected at 2 weeks. To determine the solution volume, each cubitainer was weighed after loading the limestone, after adding the influent, and at the completion of testing.

Effluent samples from the cubitainers were withdrawn through a valve using a $120 \mathrm{~mL}$ syringe. A $60 \mathrm{~mL}$ aliquot was pushed through a $0.45 \mu \mathrm{m}$ pore-size nylon filter. The first $10-\mathrm{mL}$ filtrate was discarded and the remaining $50 \mathrm{~mL}$ filtrate was analyzed for $\mathrm{pH}$, alkalinity to $\mathrm{pH} 4.5$ endpoint (American Public Health Association 1998a), and calcium concentrations by ICP-AES or colorimetric titration methods (American Public Health Association 1998b). Calcite SI and $P_{\mathrm{CO}_{2}}$ were computed with a spreadsheet model using measured values for temperature, $\mathrm{SC}, \mathrm{pH}$, alkalinity, and $\mathrm{Ca}$; van't Hoff temperature-corrected equilibrium constants from Ball and Nordstrom (1991); and Debye-Huckel activity coefficients on the basis of estimated ionic strength (Langmuir 1997).

Following the methods of Cravotta (2003), time-series data for the cubitainer tests were used to derive first-order and second-order asymptotic rate equations to estimate the concentration of alkalinity or $\mathrm{Ca}\left(C_{\mathrm{t}}\right)$ in effluent as a function of the detention time $\left(t_{\mathrm{d}}\right)$ within a limestone bed, the influent concentration $\left(C_{0}\right)$, the maximum or steadystate concentration $\left(C_{\mathrm{S}}\right)$, and the rate constant. Using the $C_{\mathrm{t}}$ data for the first $6 \mathrm{~h}$ of the cubitainer tests, linear regression of $\ln \left[\left(C_{\mathrm{S}}-C_{\mathrm{t}}\right) /\left(C_{\mathrm{S}}-C_{0}\right)\right]$ as a function of detention time yielded estimates of the first-order rate constant, $k^{\prime}$, in the expression:

$C_{\mathrm{t}}=C_{\mathrm{S}}-\left[\left(C_{\mathrm{S}}-C_{0}\right) \cdot \exp \left\{k^{\prime} \cdot t_{\mathrm{d}}\right\}\right]$

and linear regression of $\left[1 /\left(\mathrm{C}_{\mathrm{S}}-\mathrm{C}_{0}\right)-1 /\left(\mathrm{C}_{\mathrm{S}}-\mathrm{C}_{\mathrm{t}}\right)\right]$ as a function of detention time yielded estimates of the secondorder rate constant, $k^{\prime \prime}$, in the expression:

$C_{\mathrm{t}}=C_{\mathrm{S}}+\left\{1 /\left[k^{\prime \prime} \cdot t_{\mathrm{d}}-1 /\left(C_{\mathrm{S}}-C_{0}\right)\right]\right\}$.

In order to use the rate data for cubitainer tests to evaluate systems with different particle sizes, the overall rate constant $\left(k^{\prime}\right.$ or $\left.k^{\prime \prime}\right)$ was divided by the ratio of total substrate surface area $(A)$ to the average solution volume (V):

$K^{\prime}=k^{\prime} /(A / V) ; K^{\prime \prime}=k^{\prime \prime} /(A / V)$

where $K^{\prime}$ and $K^{\prime \prime}$ are the normalized first-order or secondorder rate constants, respectively. Accordingly, by assuming an ellipsoidal geometry and rearranging Eq. 13 to multiply $K^{\prime}$ or $K^{\prime \prime}$ by $A / V$ for field conditions, the overall rate constant for R-4 and R-5 particle sizes within limestone beds of treatment cells A and B could be estimated. By combining these field-corrected rate estimates with information on the initial mass of limestone, average porosity of the limestone bed, and average flow rate through the limestone bed, field-relevant, first-order and second-order decay models were obtained indicating possible relations between the mass of limestone, detention time, and effluent composition. By extrapolation, the models could indicate future changes in mass of limestone, detention time, and alkalinity of effluent on a decadal scale.

\section{Results}

\section{Limestone Characteristics}

The mineralogical, chemical, and physical characteristics of the limestone samples used for cubitainer tests and for construction of the treatment system for the Bell Discharge are described in Table 1. The calcitic limestone was dark gray with lighter-colored, rounded edges. The calcitic limestone was nearly pure calcite, with calcium of 39.9 to $40.0 \mathrm{wt} \%$, magnesium and silicon of $0.01 \mathrm{wt} \%$ or less, and the balance oxygen and carbon. The dolomitic limestone was light gray with sharp, angular edges and distinct white, crystalline veins of pure calcite (confirmed by powder X-ray diffraction) that ranged from hair-like veinlets to veins up to $1 \mathrm{~cm}$ wide and coatings on fracture surfaces. The dolomitic samples effervesced when $10 \% \mathrm{HCl}$ was dropped on the surface; however, the calcite veins reacted 
Table 1 Mineralogical, chemical, and physical characteristics of limestone used in cubitainer tests and in construction of the treatment system for the Bell Mine Discharge near Mary D, Pa

\begin{tabular}{|c|c|c|c|c|}
\hline & \multicolumn{2}{|c|}{ Dolomitic Limestone } & \multicolumn{2}{|c|}{ Calcitic Limestone } \\
\hline \multicolumn{5}{|l|}{ Minerals identified by X-Ray diffraction ${ }^{\mathrm{a}}$} \\
\hline Calcite, $\mathrm{CaCO}_{3}($ wt \%) & 11.7 & 15.6 & 99.8 & 99.9 \\
\hline Dolomite, $\mathrm{CaMg}\left(\mathrm{CO}_{3}\right)_{2}(\mathrm{wt} \%)$ & 87.5 & 83.9 & 0 & 0 \\
\hline Quartz, $\mathrm{SiO}_{2}(\mathrm{wt} \%)$ & 0.5 & 0.5 & 0.2 & 0 \\
\hline Muscovite, $\mathrm{KAl}_{3} \mathrm{Si}_{3} \mathrm{O}_{10}(\mathrm{OH})_{2}(\mathrm{wt} \%)$ & 0 & 0 & $\operatorname{tr}$ & 0 \\
\hline \multicolumn{5}{|l|}{ Constituent element concentration as oxide } \\
\hline $\mathrm{CaO}(\mathrm{wt} \%)$ & 33.2 & 34.3 & 56.0 & 56.0 \\
\hline $\mathrm{MgO}(\mathrm{wt} \%)$ & 19.2 & 18.3 & $<0.01$ & $<0.01$ \\
\hline $\mathrm{CO}_{2}(\mathrm{wt} \%)$ & 47.0 & 46.9 & 43.9 & 43.9 \\
\hline $\mathrm{SiO}_{2}(\mathrm{wt} \%)$ & 0.53 & 0.49 & 0.03 & 0.03 \\
\hline \multicolumn{5}{|l|}{ Element abundance estimates } \\
\hline $\mathrm{Ca}(\mathrm{wt} \%)$ & 23.8 & 24.5 & 39.9 & 40.0 \\
\hline $\mathrm{Mg}(\mathrm{wt} \%)$ & 11.6 & 11.1 & $<0.01$ & $<0.01$ \\
\hline $\mathrm{C}(\mathrm{wt} \%)$ & 12.8 & 12.8 & 12.0 & 12.0 \\
\hline $\mathrm{O}(\mathrm{wt} \%)$ & 51.6 & 51.4 & 48.0 & 48.0 \\
\hline $\mathrm{Si}(\mathrm{wt} \%)$ & 0.20 & 0.20 & 0.01 & $<0.01$ \\
\hline $\mathrm{Ca}$ as $\mathrm{CaCO}_{3}(\mathrm{wt} \%)^{\mathrm{b}}$ & 59.4 & 61.2 & 99.6 & 99.9 \\
\hline Elements identified by X-Ray fluorescence ${ }^{c}$ element & $\mathrm{Ca}, \mathrm{Mg}, \mathrm{Si}$ & $\mathrm{Ca}, \mathrm{Mg}, \mathrm{Si}$ & $\mathrm{Ca}, \mathrm{Si}, \mathrm{Al}$ & $\mathrm{Ca}, \mathrm{Si}$ \\
\hline Physical characteristics ${ }^{\mathrm{d}}$ & Cubitainers & Cells A \& B & Cubitainers & Cells A \& B \\
\hline Particle size range $(\mathrm{cm})$ & $1.3-3.8$ & $13-45$ & $1.3-3.8$ & $8-30$ \\
\hline Total weight $(\mathrm{kg})$ & 2.0 & $1,091,000$ & 2.0 & 300,000 \\
\hline Limestone bulk volume $\left(\mathrm{m}^{3}\right)$ & 0.00144 & 727 & 0.00130 & 200 \\
\hline Particle volume $\left(\mathrm{m}^{3}\right)$ & 0.00068 & 371 & 0.00076 & 113 \\
\hline Porosity (unitless ratio) & 0.53 & 0.49 & 0.42 & 0.43 \\
\hline Bulk density $\left(\mathrm{kg} / \mathrm{m}^{3}\right)$ & 1,390 & 1,500 & 1,540 & 1,500 \\
\hline Particle density $\left(\mathrm{kg} / \mathrm{m}^{3}\right)$ & 2,940 & 2,940 & 2,650 & 2,650 \\
\hline Unit surface area $\left(\mathrm{cm}^{2} / \mathrm{g}\right)$ & 1.54 & 0.13 & 1.44 & 0.19 \\
\hline Surface area to fluid volume ratio, $A / V\left(\mathrm{~cm}^{2} / \mathrm{L}\right)$ & 898 & 395 & 903 & 512 \\
\hline
\end{tabular}

Dolomitic limestone used in cubitainers and in treatment system from Burkholder Quarry, Lancaster County, Pa. (O'Neill 1964, pp. 4 and 25); calcitic limestone used in cubitainers from Annville Quarry, Lebanon County, Pa. (O’Neill 1964, pp. 5 and 30). Mineralogical and chemical tests reported for two samples of each rock type after the materials had been crushed, sieved, and washed for use in cubitainer tests

$\mathrm{tr}$, trace; <, less than; wt $\%$, weight percent; $\mathrm{cm}$, centimeter; $\mathrm{kg}$, kilogram; $\mathrm{m}^{3}$, cubic meter; $\mathrm{kg} / \mathrm{m}^{3}$, kilogram per cubic meter; $\mathrm{cm}^{2} / \mathrm{g}, \mathrm{square}$ centimeter per gram; $\mathrm{cm}^{2} / \mathrm{L}$, square centimeter per liter

a The amounts of each mineral identified by X-ray diffraction (XRD) and the bulk composition of the sample based on the mineralogy were estimated with the Siroquant computer program, which uses the Rietveld method on the entire XRD pattern (Taylor and Clapp 1992; Hammarstrom et al. 2003). Error on abundance estimates is 1 weight percent or less. Trace quantities of a mineral or poorly crystalline or amorphous materials may not be detected by XRD owing to low peak to background ratios for such phases

${ }^{\mathrm{b}}$ Calcium concentration expressed as calcium carbonate by mulitplying the element concentration by 2.492

${ }^{c}$ Energy dispersive X-ray fluorescence (XRF) analysis was used to qualitatively verify the chemical composition of samples

d The particle density and unit surface area of the dolomitic and calcitic limestone samples used in the cubitainer tests were estimated on the basis of the measured dimensions, weight, and volume of 50 sieved particles $(1.3$ to $3.8 \mathrm{~cm})$ of each rock sample. Dimensions and volumes for materials used to construct treatment cells A and B are consistent with physical relations described by Cravotta and Ward (2008, Fig. 1; Eqs. 8, 9) for "rip rap" R-4 and R-5 sizes (Pennsylvania Department of Environmental Protection 2000). The average unit surface area for different size particles were computed assuming an ellipsoidal sphere as the particle geometry (Eq. 6)

more vigorously than the bulk material. One dolomitic sample without visible calcite veins and one with calcite veins consisted of 11.7 and $15.6 \mathrm{wt} \%$ calcite and 87.5 and $83.9 \%$ dolomite, respectively, with concentrations of calcium of 23.8 to $24.5 \mathrm{wt} \%$, magnesium of 11.6 to $11.1 \mathrm{wt} \%$, silicon of $0.2 \mathrm{wt} \%$, and the balance oxygen and carbon (Table 1). On the basis of the mineralogy and corresponding element abundance estimates, the average $\mathrm{CaCO}_{3}$ content of the calcitic limestone was 99.6 to $99.9 \mathrm{wt} \%$ and of the dolomitic limestone was 59.5 to $61.2 \mathrm{wt} \%$ (Table 1). 
As described above, the limestone particles for the cubitainer tests were sieved to 1.3 to $3.8 \mathrm{~cm}$, consistent with Pennsylvania aggregate size class 2NS (Pennsylvania Department of Environmental Protection 2000). Despite similar processing, the calcitic limestone fragments generally were larger and more rounded than the dolomitic fragments. A subsample of 50 sieved calcitic limestone fragments had a total weight of $671.0 \mathrm{~g}$; total particle volume of $252.8 \mathrm{~cm}^{3}$; and average short and long axis lengths of 1.31 and $3.23 \mathrm{~cm}$, respectively. Given the relations between the particle weight, volume, and axis dimensions (Eqs. 6, 7, 8, and 10), the following averages were computed for the calcitic limestone: particle density of $2.65 \mathrm{~g} / \mathrm{cm}^{3}$; bulk density of $1.54 \mathrm{~g} / \mathrm{cm}^{3}$; bulk porosity of 0.42 ; and average unit surface area of $1.44 \mathrm{~cm}^{2} / \mathrm{g}$ (Table 1). A subsample of 50 sieved dolomitic limestone fragments had a total weight of $418.0 \mathrm{~g}$, total particle volume of $142.1 \mathrm{~cm}^{3}$, and average short and long axis lengths of 1.12 and $2.53 \mathrm{~cm}$, respectively. The dolomitic limestone particles had an average particle density of $2.94 \mathrm{~g} / \mathrm{cm}^{3}$, bulk density of $1.39 \mathrm{~g} / \mathrm{cm}^{3}$, bulk porosity of 0.53 , and average unit surface area of $1.54 \mathrm{~cm}^{2} / \mathrm{g}$
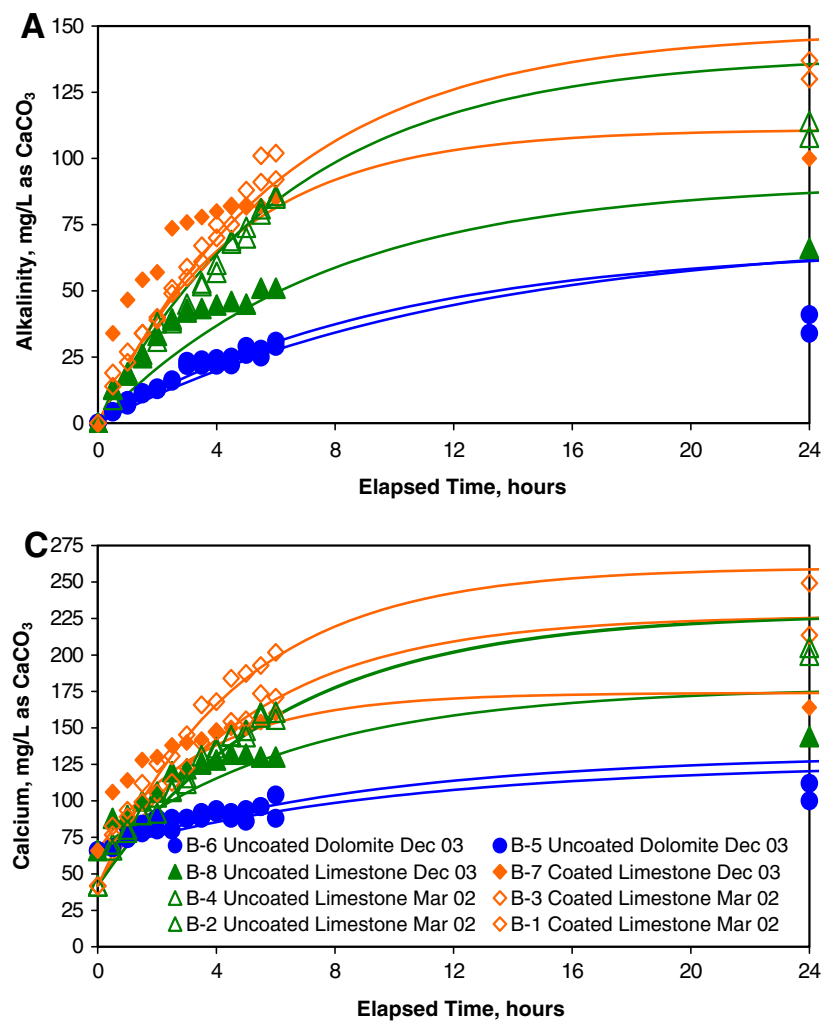

Fig. 1 Concentrations of alkalinity and calcium as $\mathrm{CaCO}_{3}$ with elapsed time of contact between Bell Discharge effluent and uncoated or $\mathrm{Fe}(\mathrm{OH})_{3}$-coated calcitic limestone or uncoated dolomitic limestone in collapsible, closed-containers (cubitainers): a Alkalinity, first-order curve; b alkalinity, second-order curve; $\mathbf{c} \mathrm{Ca}$, first- order curve; $\mathbf{d ~ C a}$, second-order curve. Calcitic limestone immersed in flowing effluent
(Table 1). Given larger unit surface area and porosity, a $2 \mathrm{~kg}$ sample of the sieved dolomitic limestone would have greater exposure to surrounding fluid in the cubitainers than a $2 \mathrm{~kg}$ sample of the sieved calcitic limestone.

The large, R-5 dolomitic limestone particles used for the lower treatment beds in cells A and B had axis dimensions ranging from 13 to $45 \mathrm{~cm}$. In contrast, smaller, R-4 size calcitic limestone particles used to construct the upper treatment beds had axis dimensions ranging from 8 to $30 \mathrm{~cm}$. Given the reported total weight of limestone used to construct the treatment system and the approximate dimensions of the limestone beds (Cravotta and Ward 2008, Fig. 1), combined with the particle density for calcitic limestone and dolomitic limestone used for cubitainer tests, estimates were computed for the bulk volume, bulk density, porosity, and void volume of the treatment beds (Table 1). Assuming an ellipsoidal sphere as the particle geometry (Eq. 6), the unit surface area of the R-5 size dolomitic fragments was computed to be $0.13 \mathrm{~cm}^{2} / \mathrm{g}$ and that of the R-4 size calcitic fragments was computed to be $0.19 \mathrm{~cm}^{2} / \mathrm{g}$ (Table 1). Hence, the R-4 and R-5 aggregate used to construct the treatment system had unit surface
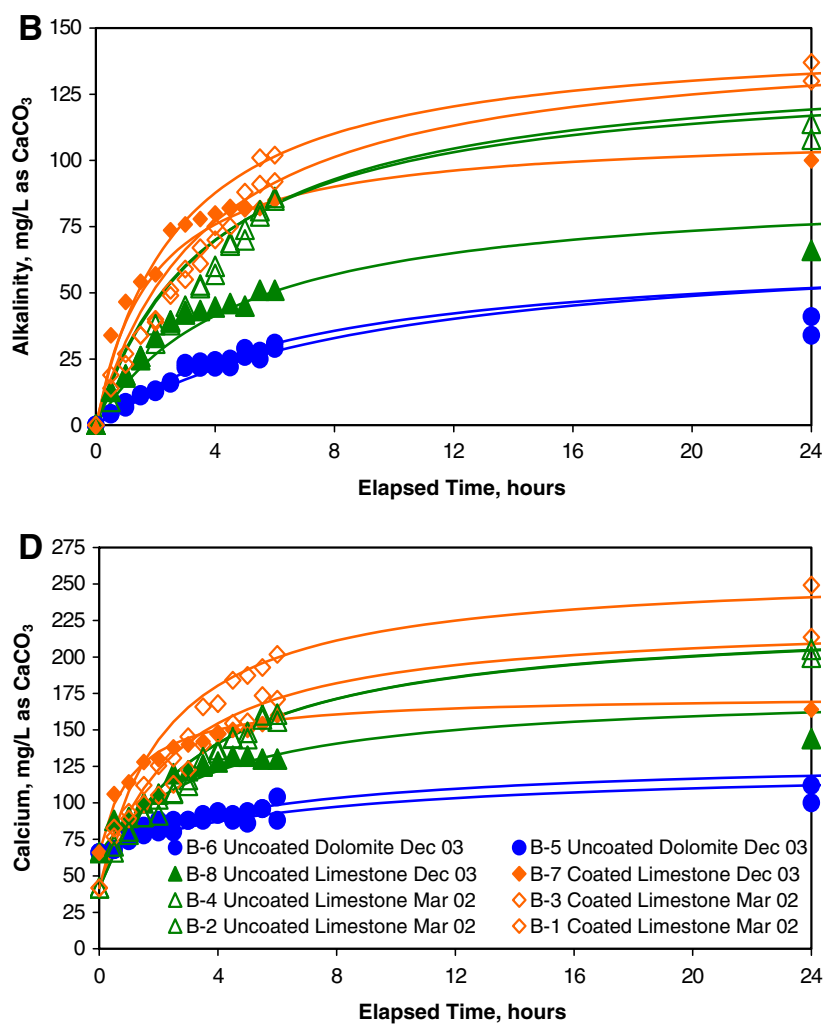

at Bell Discharge for 6 wks became coated with $\mathrm{Fe}(\mathrm{OH})_{3}$. Cubitainer tests were conducted in March 2002 and December 2003 with 2.0-kg limestone under closed, circulated conditions. First- and second-order asymptotic curves were derived using Eqs. 11 and 12, respectively, with concentration data and rate estimates reported in Tables 2 and 3 
areas that were approximately an order of magnitude less than those of particles used in cubitainer tests.

\section{Laboratory Neutralization-Rate Experiments}

The laboratory neutralization-rate experiments in March 2002 and December 2003 demonstrated the chemical evolution of AMD from the Bell Discharge in contact with particles of calcitic limestone or dolomitic limestone in enclosed cubitainers. The $\mathrm{pH}$, alkalinity, and calcium of effluent samples collected from the cubitainers over an elapsed time of 2 weeks are summarized in Table 2 and Fig. 1. Although the concentrations of acidity and dissolved magnesium, iron, manganese, aluminium, and other metals in effluent also were likely to evolve, these constituents were not measured for the cubitainer effluent.

For each of the three test conditions (uncoated, dolomitic limestone; uncoated, calcitic limestone; $\mathrm{Fe}(\mathrm{OH})_{3^{-}}$ coated, calcitic limestone), the $\mathrm{pH}$, alkalinity, and calcium concentrations in the effluent increased rapidly during the first few hours and thereafter gradually approached "steady-state" or equilibrium conditions within approximately 2 weeks (336 h) of continuous contact between the AMD and limestone (Table 2, Fig. 1). These asymptotic trends indicated a progressive decline in the limestone dissolution rate as the effluent approached equilibrium with calcite (Table 3, SI $=0.0$ ). At the start of the tests in March 2002 and December 2003, the AMD influent had pH of 4.4 and 4.1 and net acidity of 35 and $14 \mathrm{mg} / \mathrm{L} \mathrm{CaCO}_{3}$, respectively. After only $1 \mathrm{~h}$ of contact between the AMD and the limestone, the $\mathrm{pH}$ for all tests increased to values ranging from 5.3 to 6.0 (Table 2). After $3 \mathrm{~h}$ of contact, all the tests produced net-alkaline effluent (alkalinity $>$ initial net acidity) with $\mathrm{pH}$ and alkalinity values ranging from 6.0 to 6.1 and 22 to $23 \mathrm{mg} / \mathrm{L} \mathrm{CaCO}_{3}$ for uncoated dolomitic limestone, 6.3 to 6.4 and 42 to $45 \mathrm{mg} / \mathrm{L} \mathrm{CaCO}_{3}$ for uncoated calcitic limestone, and 6.4 to 6.9 and 55 to

Table $2 \mathrm{pH}$, alkalinity, and calcium concentrations in effluent from Bell Mine Discharge after reaction with limestone in closed cubitainers

\begin{tabular}{|c|c|c|c|c|c|c|c|c|c|c|c|c|c|c|c|c|c|c|c|c|c|c|c|c|}
\hline \multirow{4}{*}{$\begin{array}{l}\text { Elapsed } \\
\text { time (h) } \\
\\
0.0\end{array}$} & \multicolumn{6}{|c|}{ Uncoated dolomitic limestone } & \multicolumn{9}{|c|}{ Uncoated calcitic limestone } & \multicolumn{9}{|c|}{ Coated $^{\mathrm{a}}$ calcitic limestone } \\
\hline & \multicolumn{3}{|c|}{ B5/Dec03 } & \multicolumn{3}{|c|}{ B6/Dec03 } & \multicolumn{3}{|c|}{ B2/Mar02 } & \multicolumn{3}{|c|}{ B4/Mar02 } & \multicolumn{3}{|c|}{ B8/Dec03 } & \multicolumn{3}{|c|}{ B1/Mar02 } & \multicolumn{3}{|c|}{ B3/Mar02 } & \multicolumn{3}{|c|}{ B7/Dec03 } \\
\hline & \multirow{2}{*}{$\begin{array}{r}\mathrm{pH} \\
4.1\end{array}$} & \multicolumn{2}{|c|}{$\begin{array}{l}\text { Alk Ca } \\
(\mathrm{mg} / \mathrm{L})\end{array}$} & \multirow{2}{*}{$\begin{array}{c}\mathrm{pH} \\
4.1\end{array}$} & \multicolumn{2}{|c|}{$\begin{array}{l}\text { Alk Ca } \\
(\mathrm{mg} / \mathrm{L})\end{array}$} & \multirow{2}{*}{$\begin{array}{r}\mathrm{pH} \\
4.4\end{array}$} & \multicolumn{2}{|c|}{$\begin{array}{l}\text { Alk Ca } \\
(\mathrm{mg} / \mathrm{L})\end{array}$} & \multirow{2}{*}{$\begin{array}{c}\mathrm{pH} \\
4.4\end{array}$} & \multicolumn{2}{|c|}{$\begin{array}{l}\text { Alk Ca } \\
(\mathrm{mg} / \mathrm{L})\end{array}$} & \multirow{2}{*}{$\begin{array}{c}\mathrm{pH} \\
4.1\end{array}$} & \multicolumn{2}{|c|}{$\begin{array}{l}\text { Alk Ca } \\
(\mathrm{mg} / \mathrm{L})\end{array}$} & \multirow{2}{*}{$\begin{array}{c}\mathrm{pH} \\
4.4\end{array}$} & \multicolumn{2}{|c|}{$\begin{array}{l}\text { Alk Ca } \\
(\mathrm{mg} / \mathrm{L})\end{array}$} & \multirow{2}{*}{$\frac{\mathrm{pH}}{4.4}$} & \multicolumn{2}{|c|}{$\begin{array}{l}\text { Alk Ca } \\
(\mathrm{mg} / \mathrm{L})\end{array}$} & \multirow{2}{*}{$\begin{array}{l}\mathrm{pH} \\
4.1\end{array}$} & $\begin{array}{l}\text { Alk } \\
(\mathrm{mg} / \mathrm{L}\end{array}$ & $\begin{array}{l}\mathrm{Ca} \\
\mathrm{L})\end{array}$ \\
\hline & & 0 & 66 & & 0 & 66 & & 0 & 42 & & 0 & 42 & & 0 & 66 & & 0 & 42 & & 0 & 42 & & 0 & 66 \\
\hline 0.5 & 5.1 & 4 & 68 & 5.1 & 4 & 68 & 5.4 & 9 & 67 & 5.5 & 13 & 71 & 5.7 & 13 & 88 & 5.8 & 14 & 83 & 5.7 & 19 & 77 & 6.3 & 34 & 106 \\
\hline 1.0 & 5.5 & 9 & 82 & 5.3 & 7 & 74 & 5.8 & 19 & 81 & 5.8 & 19 & 79 & 5.9 & 18 & 90 & 5.8 & 23 & 94 & 6.0 & 27 & 89 & 6.3 & 47 & 114 \\
\hline 1.5 & 5.6 & 11 & 84 & 5.6 & 12 & 78 & 5.9 & 26 & 91 & 6.0 & 26 & 91 & 6.1 & 25 & 100 & 6.1 & 34 & 112 & 6.1 & 34 & 99 & 6.5 & 54 & 128 \\
\hline 2.0 & 5.9 & 13 & 88 & 5.8 & 13 & 80 & 6.1 & 38 & 103 & 6.1 & 31 & 92 & 6.4 & 33 & 106 & 6.2 & 40 & 126 & 6.2 & 39 & 105 & 6.5 & 57 & 130 \\
\hline 2.5 & 5.9 & 16 & 88 & 5.9 & 16 & 80 & 6.2 & 39 & 107 & 6.2 & 38 & 107 & 6.3 & 39 & 120 & 6.3 & 51 & 131 & 6.3 & 49 & 113 & 6.7 & 74 & 138 \\
\hline 3.0 & 6.1 & 23 & 88 & 6.0 & 22 & 88 & 6.3 & 45 & 112 & 6.3 & 43 & 116 & 6.4 & 42 & 122 & 6.4 & 59 & 145 & 6.5 & 55 & 123 & 6.9 & 76 & 140 \\
\hline 3.5 & 6.1 & 24 & 92 & 6.1 & 22 & 88 & 6.4 & 53 & 131 & 6.3 & 52 & 125 & 6.4 & 43 & 126 & 6.2 & 67 & 166 & 6.4 & 61 & 140 & 6.8 & 78 & 142 \\
\hline 4.0 & 6.0 & 24 & 94 & 6.1 & 22 & 92 & 6.4 & 60 & 135 & 6.5 & 57 & 137 & 6.4 & 45 & 128 & 6.4 & 75 & 168 & 6.5 & 70 & 147 & 6.8 & 80 & 148 \\
\hline 4.5 & 6.2 & 25 & 88 & 6.1 & 22 & 92 & 6.5 & 68 & 144 & 6.5 & 69 & 145 & 6.4 & 46 & 132 & 6.6 & 82 & 184 & 6.6 & 75 & 155 & 6.8 & 82 & 150 \\
\hline 5.0 & 6.2 & 29 & 94 & 6.1 & 26 & 86 & 6.6 & 74 & 144 & 6.6 & 70 & 148 & 6.4 & 45 & 132 & 6.7 & 88 & 187 & 6.7 & 82 & 156 & 6.8 & 82 & 150 \\
\hline 5.5 & 6.3 & 28 & 96 & 6.2 & 25 & 96 & 6.6 & 79 & 158 & 6.7 & 81 & 160 & 6.6 & 51 & 130 & 6.7 & 101 & 193 & 6.7 & 91 & 174 & 7.0 & 82 & 154 \\
\hline 6.0 & 6.3 & 31 & 104 & 6.2 & 29 & 88 & 6.7 & 85 & 161 & 6.7 & 86 & 156 & 6.6 & 51 & 130 & 6.8 & 102 & 202 & 6.9 & 92 & 171 & 7.0 & 85 & 160 \\
\hline 24 & 6.3 & 34 & 112 & 6.5 & 41 & 100 & 7.0 & 108 & 205 & 7.1 & 114 & 200 & 6.8 & 66 & 144 & 6.9 & 137 & 249 & 7.1 & 130 & 214 & 7.3 & 100 & 164 \\
\hline 144 & 6.7 & 57 & 124 & 6.8 & 66 & 126 & 7.2 & 127 & nd & 7.4 & 133 & nd & 7.1 & 82 & 176 & 7.4 & 138 & nd & 7.3 & 141 & nd & 7.4 & 102 & 174 \\
\hline 336 & 7.0 & 67 & 132 & 7.0 & 72 & 126 & 7.2 & 134 & 229 & 7.4 & 138 & 229 & 7.5 & 91 & 178 & 7.3 & 143 & 260 & 7.4 & 148 & 227 & 7.7 & 111 & 170 \\
\hline
\end{tabular}

Cubitainer tests conducted at U.S. Geological Survey Water Science Center, New Cumberland, Pennsylvania, March 11-28, 2002 and December 23, 2003-January 6, 2004, following methods of Cravotta (2003). Each test was conducted at $5^{\circ} \mathrm{C}$ under closed, circulated conditions (10 to $30 \mathrm{~L} / \mathrm{h}$ ) and used $2 \mathrm{~kg}$ of sieved, pre-rinsed limestone fragments and untreated effluent from the Bell Discharge. Data on chemical and physical characteristics of dolomitic limestone $\left(\mathrm{CaCO}_{3}=0.60\right.$ weight percent $)$ and calcitic limestone $\left(\mathrm{CaCO}_{3}=0.99\right.$ weight percent $)$ used in tests are shown in Table 1. The $\mathrm{pH}$, alkalinity, and calcium concentration of effluent samples were measured after filtration though 0.45 - $\mu \mathrm{m}$ pore-size filter. Alkalinity was determined by electrometric titration to $\mathrm{pH} 4.5$ endpoint (American Public Health Association 1998a). In March 2002, calcium concentration was determined by inductively coupled atomic emission spectrometry; in December 2003, calcium concentration was determined by colorimetric titration (American Public Health Association 1998b). Additional data for samples at 0 and $336 \mathrm{~h}$ are shown in Table 3

$\mathrm{h}$, hour; mg/L, milligrams per liter as calcium carbonate; "nd" no data;

${ }^{a}$ Coated calcitic limestone became encrusted with Fe-hydroxide after 6 weeks contact with effluent at Bell Mine Discharge prior to cubitainer tests in March 2002; the same material was reused in December 2003 


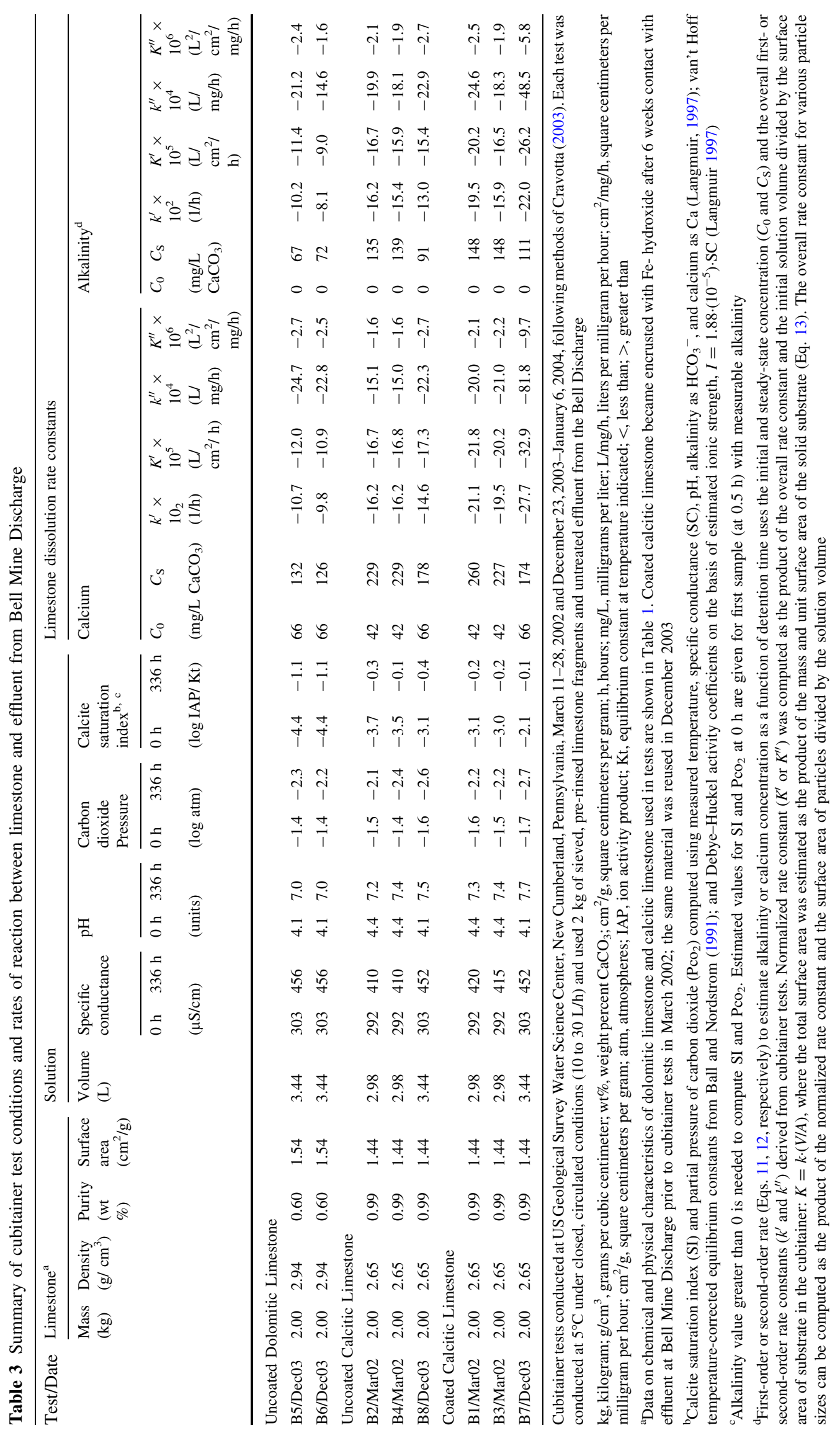


$76 \mathrm{mg} / \mathrm{L} \mathrm{CaCO}_{3}$ for $\mathrm{Fe}(\mathrm{OH})_{3}$-coated calcitic limestone (Table 2). Nevertheless, the dissolution rate of uncoated dolomitic limestone was substantially less than the dissolution rate of calcitic limestone. Although results for duplicate tests varied and the trends for uncoated and $\mathrm{Fe}(\mathrm{OH})_{3}$-coated calcitic limestone overlapped, the concentrations of alkalinity and calcium for tests with $\mathrm{Fe}(\mathrm{OH})_{3}$-coated or uncoated calcitic limestone consistently were greater and increased at faster rates than corresponding data for uncoated dolomitic limestone (Fig. 1).

The calcium and alkalinity concentration data for the first $6 \mathrm{~h}$ of cubitainer testing and the maximum or steadystate concentrations at $336 \mathrm{~h}$ were used to compute firstorder and second-order rate estimates of the concentration trends during the cubitainer tests (Table 3). The resultant asymptotic curves for calcium and alkalinity concentration as a function of detention time for each test are shown with the corresponding data points (Fig. 1). As shown in Fig. 1, the second-order estimates (Eq. 12) approximated the observed calcium and alkalinity concentration trends better than the first-order estimates (Eq. 11).

\section{Discussion: Modeling of Limestone Dissolution and Treatment-System Performance}

\section{Simulation of Limestone Dissolution and Alkalinity Production Rates}

Using the second-order estimates for the laboratory dissolution-rate experiments, kinetic models were developed to evaluate the effects of detention time, limestone purity, and $\mathrm{Fe}(\mathrm{OH})_{3}$ coatings on limestone dissolution rates and the corresponding production of alkalinity in the Bell Discharge treatment system. Although the limestone used in the cubitainer tests had chemical and mineralogical characteristics representative of the materials used to construct the treatment system, it consisted of small particles with large unit surface area and was reacted with a volume of fluid greater than the void volume (Table 1). To normalize the cubitainer rate constants for various sizes of particles and volumes of AMD in contact with the limestone, the overall rate constants were divided by the surface area to volume ratio for the cubitainers (Eq. 13). For application to the Bell Discharge treatment system, the normalized rate constants were multiplied by the corresponding total surface area to void-volume ratio for the R-5 and R-4 limestone in cells A and B (Tables 1 and 3). The resultant second-order rate models for predicted alkalinity and calcium concentrations as a function of detention time in the limestone beds of the treatment system are displayed in Fig. 2. These models were generated using the average values for the rate constants derived from cubitainer tests with uncoated dolomitic limestone, uncoated calcitic limestone, and $\mathrm{Fe}(\mathrm{OH})_{3}$-coated calcitic limestone (Table 3). To compare field reaction rates with the cubitainer rate models, the detention times for the field observations were computed by dividing the void volume of the limestone bed by the average flow rate from the outlet pipe (Cravotta and Ward 2008, Eq. 7).

The second-order rate models derived from the cubitainer tests generally are consistent with observed data for the effluent from outlet pipes of cells A and B of the Bell Discharge treatment system and indicate the alkalinity and calcium concentrations increase with detention time within the limestone beds (Fig. 2). Because the role of dolomitic limestone under field conditions was uncertain, the observed concentration data were plotted relative to the detention time within the calcitic limestone bed only (solid symbols) and within the calcitic and dolomitic limestone beds combined (open symbols). As explained by Cravotta and Ward (2008), small increases in the concentration of
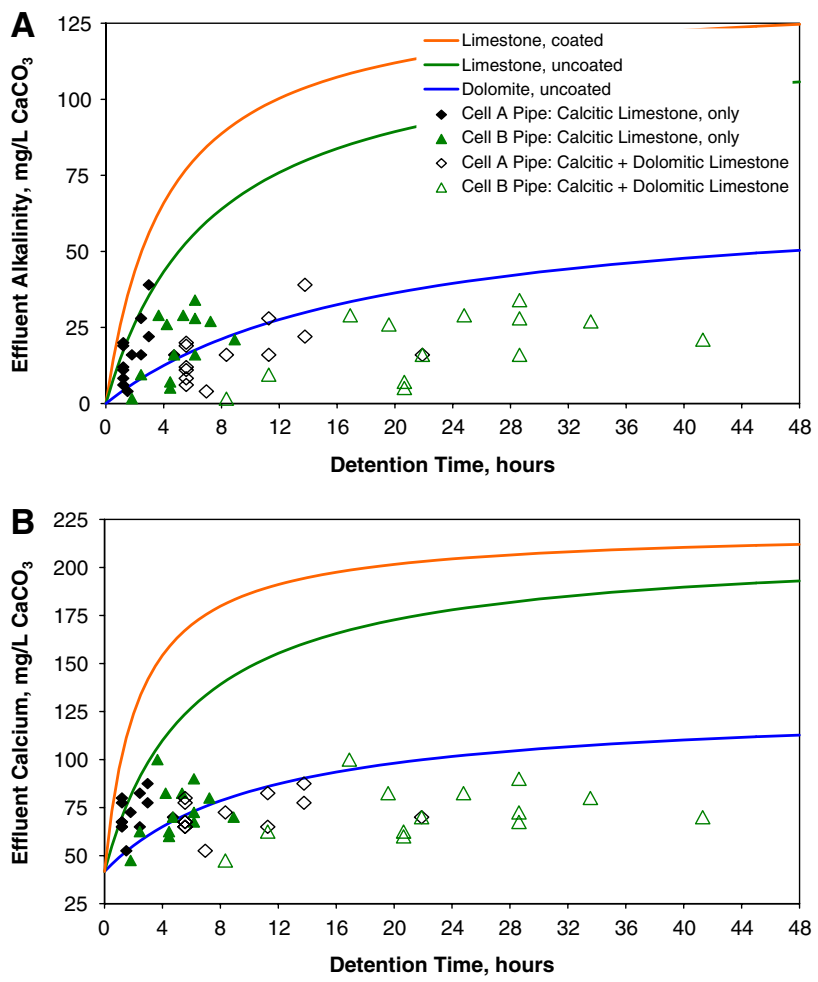

Fig. 2 Measured and simulated effect of detention time within limestone beds of Cells A and B of the Bell Mine Discharge treatment system on $\mathrm{CaCO}_{3}$ concentration: a Alkalinity; b calcium. Point symbols show observed monthly alkalinity or calcium concentration at outflow pipes and computed detention time (Cravotta and Ward, 2008, Eq. 7) within the calcitic limestone bed only (solid symbols) or within the calcitic and dolomitic limestone beds combined (open symbols). Curves for coated calcitic limestone, uncoated calcitic limestone, and uncoated dolomitic limestone computed on the basis of averages for cubitainer tests with the specified substrate and secondorder rate constants for Eq. 12 (Table 3 ) 
magnesium compared to calcium and alkalinity in effluent from the treatment system indicate that the dolomitic limestone was relatively unreactive and unimportant as a source of alkalinity compared to the calcitic limestone.

The rate model for uncoated calcitic limestone can explain the observed data for cell $\mathrm{A}$, assuming that all of the alkalinity and calcium were acquired only from the upper limestone bed of the Bell Discharge treatment system (Fig. 2). However, the rate model for the uncoated dolomitic limestone also can explain these data assuming that the alkalinity and calcium were acquired from both the upper and lower limestone beds. The actual situation probably lies between these two extremes. This is consistent with results from the laboratory rate models that indicated the overall rate of dissolution of dolomitic limestone was less than half that of the calcitic limestone (Figs. 1, 2). Hence, the dissolution of calcitic limestone is the predominant mechanism, but not solely responsible, for neutralizing AMD within cell A.

Although the effluent from cell A may be explained by the rate model for dissolution of calcitic limestone, the effluent from the outlet pipe of cell B of the Bell Discharge treatment system contained lower concentrations of alkalinity and calcium compared to estimates on the basis of the cubitainer rate models and the computed detention times. Generally, the observed data for cell B are approximated by the rate model for dissolution of dolomitic limestone. However, the agreement between the model and observed data is poor. Poor agreement between the observed data for cell B outlet pipe and the cubitainer models could result from short-circuiting of flow past the limestone beds. As explained by Cravotta and Ward (2008), the effluent that ultimately was sampled from the outlet pipe of cell B represented a mixture of influent that bypassed the treatment media and partly treated effluent that had contact with the dolomitic limestone.

\section{Treatment-System Performance}

Following methods proposed by Cravotta (2003), the cubitainer dissolution-rate estimates (Tables 2, 3) were extrapolated to indicate long-term decreases in the mass of limestone and associated alkalinities resulting from the reaction of AMD with calcitic limestone at the Bell Discharge treatment system (Fig. 3). The initial mass of $300 \mathrm{t}$ limestone in these decadal-scale models is the quantity of calcitic limestone used to construct the upper layer of cells A or B. Detention time within the limestone bed was computed assuming constant median flow rates at the outlet pipe for each of cell A $(15.1 \mathrm{~L} / \mathrm{s})$ and cell B $(4.8 \mathrm{~L} / \mathrm{s})$ and assuming a constant porosity of 0.49 . Calculations of detention time and corresponding concentrations and fluxes of $\mathrm{CaCO}_{3}$ (calcium, alkalinity) were repeated for sequential time steps to indicate long-term, future trends. Decreases in the limestone mass and associated detention time with increased age of the treatment system were estimated by subtracting the load of calcium as $\mathrm{CaCO}_{3}$ produced at the previous time step from the limestone mass at the current time step. As the limestone mass decreased with age, its total volume was assumed to decrease proportionally, whereas the porosity and flow rates were assumed to remain constant.

The cubitainer test results extrapolated over a decadal time scale indicated that the effectiveness of treating the AMD at Bell Mine could decline rapidly, with net-acidic effluent possible at an age of 5 to 10 years, when the effluent alkalinity becomes less than the median net acidity of $20 \mathrm{mg} / \mathrm{L} \mathrm{CaCO}_{3}$ of the Bell AMD inflow (horizontal line; Cravotta and Ward 2008). As explained above, most of the treatment at the Bell Mine resulted from the dissolution of calcitic limestone that was added as the top layer in cells $\mathrm{A}$ and $\mathrm{B}$; hence, the cubitainer models shown in Fig. 3 illustrate trends for the calcitic limestone layer only. Simulations of the limestone dissolution extrapolated over a decadal time scale show the observed data are consistent with cubitainer models for long-term decay. Two additional symbols are shown in Fig. 3 for September 2007 (3.5 year age) to indicate the current estimated mass of limestone remaining in cell A or cell B could range from $182 \mathrm{t}$ to $241 \mathrm{t}$. That is, approximately $2 / 3$ of the original calcitic limestone remains after only 3.5 year of treatment, and the system will slowly become less effective with age. Because of its larger initial mass and slower dissolution rate, the dolomitic material will persist for a much longer time and could be beneficial as a base layer as used within the Bell Discharge treatment system. The dolomitic limestone could be expected to maintain its high transmissivity and integrity in the vicinity of the perforated pipe flushing system, while providing a moderate benefit as a secondary source of alkalinity. The periodic addition of high-purity calcitic limestone could increase the duration of effective treatment, ensuring net- alkaline effluent over a 20 -year life span for the system.

The simulation of limestone dissolution within a treatment system on the basis of short-term cubitainer tests (Figs. 2, 3) should be considered a rudimentary indication of possible long-term field performance because few variables could be evaluated and/or were assumed constant. Generally, laboratory testing of the reaction between AMD and limestone in cubitainers can help indicate possible rates of AMD neutralization by different substrates, identify possible long-term performance trends, and evaluate strategies for the design of a treatment system. For example, tests can be designed to evaluate the effects of mixing or layering components such as compost, calcitic 

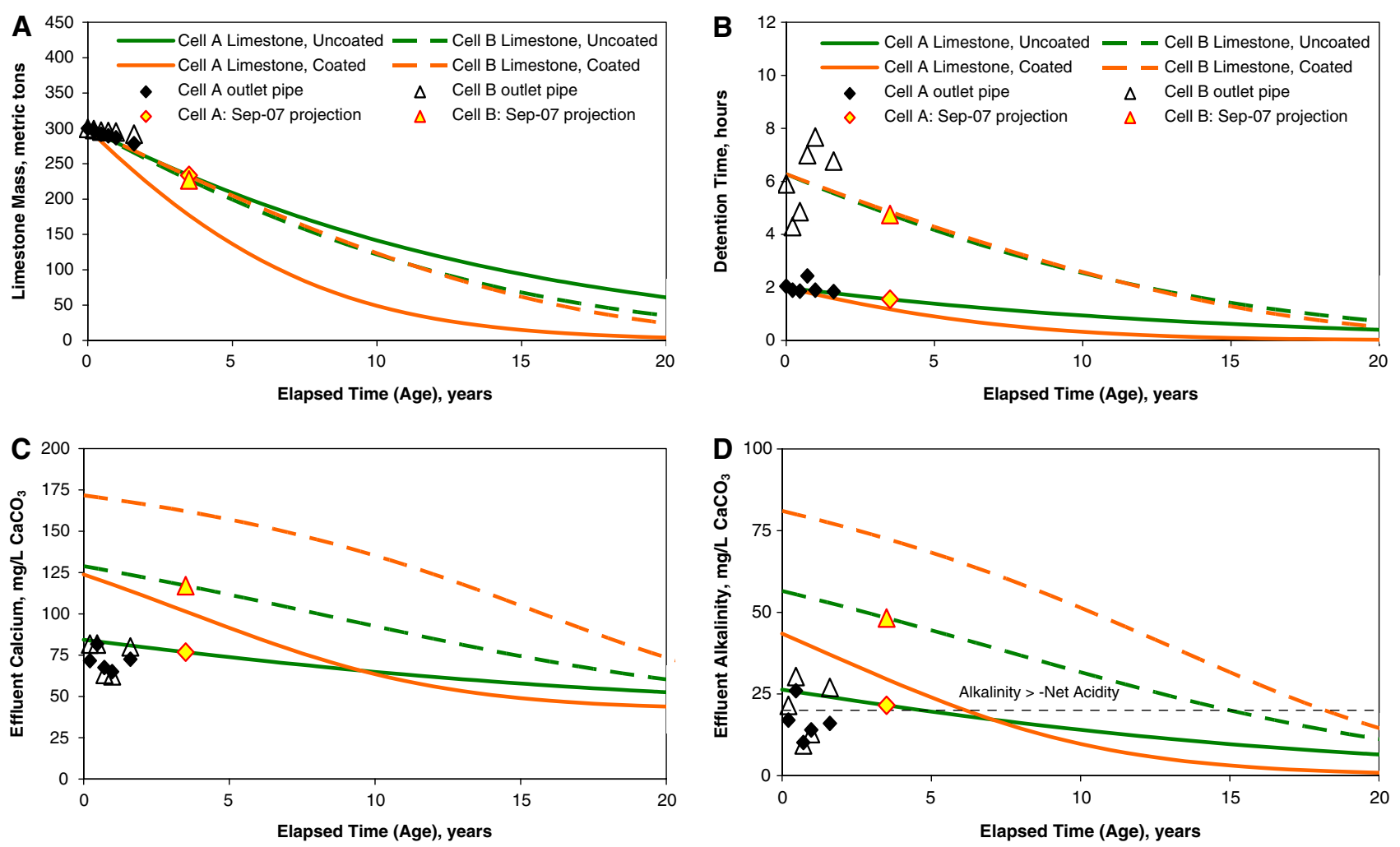

Fig. 3 Simulated decreases in calcitic limestone mass, detention time, and alkalinity with age of Bell Mine Discharge treatment system based on second-order estimates for calcium and alkalinity production rates by coated or uncoated calcitic limestone in cubitainers: a mass; $\mathbf{b}$ detention time; $\mathbf{c}$ calcium concentration; $\mathbf{d}$ alkalinity concentration. Computations use averages for initial and final concentrations and

limestone, dolomitic limestone, and/or other substrates that combined, or alone, could be effective for alkalinity production and metals removal (e.g. Sterner et al. 1998; Watzlaf 1997). Such testing could evaluate the effects of particle sizes on dissolution rates and permeability and the potential for long-term treatment.

\section{Summary and Conclusions}

We evaluated the chemical and mineralogical characteristics of calcitic limestone and dolomitic limestone and their effectiveness in neutralization of net-acidic, oxic, ironladen AMD from a flooded anthracite mine. Dolomitic limestone with a $\mathrm{CaCO}_{3}$ content of approximately $60 \mathrm{wt} \%$ and calcitic limestone with a $\mathrm{CaCO}_{3}$ content of at least 95 wt $\%$, which had been used to construct the Bell Discharge treatment system in east-central Pennsylvania, were tested in the laboratory for their composition, approximate surface area, and rate of reaction with the untreated AMD. The laboratory dissolution-rate experiments with $2 \mathrm{~kg}$ of limestone in enclosed cubitainers (cubitainers) demonstrated that AMD from the Bell Mine could be neutralized by

rate constants, k", for specified conditions (Table 3) and assume constant flow rate of $909 \mathrm{~L} / \mathrm{min}$ for Cell A and $289 \mathrm{~L} / \mathrm{min}$ for Cell B, bulk porosity of 0.49 , particle density of $2.65 \mathrm{~g} / \mathrm{cm}^{3}$, and surface area of $0.19 \mathrm{~cm}^{2} / \mathrm{g}$ for "R-4" size limestone. Symbols based on quarterly average flow and $\mathrm{CaCO}_{3}$ concentrations for outlet pipes of Cells $\mathrm{A}$ and $\mathrm{B}$

reaction with dolomitic limestone or calcitic limestone, even if the limestone particles were thinly coated by $\mathrm{Fe}(\mathrm{OH})_{3}$. After $3 \mathrm{~h}$ of contact between the AMD and limestone in the cubitainers, a net-alkaline effluent was produced by all the materials tested. Nevertheless, the dissolution rates and corresponding alkalinity production rates for the calcitic limestone were more than two times that of the dolomitic limestone. Greater production of calcium and alkalinity indicate that calcitic limestone would be more effective than the same mass of dolomitic limestone for neutralization of AMD; however, because of its higher rate of dissolution, the calcitic limestone would be depleted before the dolomitic limestone.

Laboratory tests of the reaction rate between AMD and different samples of limestone can be helpful for the design and the evaluation of limestone-based passive-treatment systems. Dissolution-rate models based on cubitainer tests of the reaction between the Bell AMD and calcitic limestone extrapolated over a decadal time scale indicated that the effectiveness of the treatment system at the Bell Mine could decline rapidly because of depletion of the calcitic limestone. With the depletion of the calcitic limestone and a corresponding decrease in detention time within the 
limestone bed, a net-acidic effluent could develop within 5 to 10 years. Hence, the periodic addition of calcitic limestone to the treatment system may be necessary to ensure its effectiveness.

As demonstrated in this study and the companion paper by Cravotta and Ward (2008), the performance of the Bell Discharge treatment system and, possibly, other passivetreatment systems for treatment of net-acidic AMD may be ensured by using high-purity calcitic limestone to increase $\mathrm{pH}$, add alkalinity, and accelerate metals removal and by using dolomitic limestone as an underlying base substrate for the flushing system. The relative stability of the dolomitic limestone and the use of this material as a base substrate could be beneficial over the long term. Because it dissolved slowly compared to the overlying calcitic limestone, the dolomitic limestone could be expected to maintain its initial transmissivity and structural integrity in the vicinity of the perforated pipe flushing system, while providing a moderate benefit as a secondary source of alkalinity.

Acknowledgments This project was conducted by the US Geological Survey (USGS) in cooperation with the Schuylkill Conservation District (SCD) and the Pennsylvania Department of Environmental Protection (PaDEP). Michael Asmussen, student volunteer formerly of Dickinson College, conducted measurements and computations of physical properties of limestone. The manuscript benefited from reviews by Kevin Breen, Daniel Hippe, Robert Runkel, and Dorothy Tepper of USGS and two anonymous reviewers. Use of trade, firm, or product names is for descriptive purposes only and does not imply endorsement by the U.S. Government.

\section{References}

American Public Health Association (1998a) Alkalinity (2320)/ Titration method. In: Clesceri LS, Greenberg AE, Eaton AD (eds) Standard methods for the examination of water and Wastewater. 20th edn. American Public Health Assoc, Washington, DC, pp 2.26-2.30

American Public Health Association (1998b) Calcium (3500-Ca). In: Clesceri LS, Greenberg AE, Eaton AD (eds) Standard methods for the examination of water and wastewater, 20th edn, American Public Health Assoc, Washington, DC, pp 3.63-3.65

Ball JW, Nordstrom DK (1991) User's manual for WATEQ4F with revised data base: USGS Open-File Report 91-183, www.brr.cr.usgs.gov/projects/GWC_chemtherm/pubs/wq4fdoc. pdf, $189 \mathrm{pp}$

Cravotta CA III (2003) Size and performance of anoxic limestone drains to neutralize acidic mine drainage. J Environ Qual 32:1277-1289

Cravotta CA III, Trahan MK (1999) Limestone drains to increase $\mathrm{pH}$ and remove dissolved metals from acidic mine drainage. Appl Geochem 14:581-606

Cravotta CA III, Ward SJ (2008) Downflow limestone beds for treatment of net-acidic, oxic, iron-laden drainage from a flooded anthracite mine, Pennsylvania, USA: 1. Field evaluation: Mine Water Environ (this issue)

Cravotta CA III, Ward SJ, Koury DJ, Koch RD (2004) Optimization of limestone drains for long-term treatment of acidic mine drainage, Swatara Creek Basin, Schuylkill County, PA. Proc, 2004 National Meeting of the American Soc of Mining and Reclamation and the 25th WV Surface Mine Drainage Task Force, pp 366-411

Cravotta CA III, Watzlaf GR (2002) Design and performance of limestone drains to increase $\mathrm{pH}$ and remove dissolved metals from acidic mine drainage. In: Naftz DL, Morrison SJ, Fuller CC, Davis JA (eds) Handbook of Groundwater remediation using permeable reactive barriers-applications to radionuclides, trace Metals, and nutrients. Academic Press, San Diego, pp 19-66

Hammarstrom JM, Sibrell PL, Belkin HE (2003) Characterization of limestone reacted with acid-mine drainage in a pulsed limestone bed treatment system at the Friendship Hill National Historic Site, Pennsylvania, USA. Appl Geochem 18:1705-1721

Hedin RS, Nairn RW, Kleinmann RLP (1994) Passive treatment of coal mine drainage. USBM IC 9389, $35 \mathrm{pp}$

Hedin RS, Watzlaf GR (1994) The effects of anoxic limestone drains on mine water chemistry. USBM SP 06A, pp 185-194

Hedwin Corporation (2007) Cubitainer ${ }^{\circledR}$ combination package: Baltimore, Md., Hedwin Corporation http://www.hedwin.com/ library/pdfs/cubitainer_info.pdf, 3 pp

Herman JS, White WB (1985) Dissolution kinetics of dolomiteEffects of lithology and fluid flow velocity. Geochim Cosmochim Acta 49:2017-2026

Huminicki DMC, Rimstidt JD (2007) Neutralization of sulfuric acid solutions by calcite dissolution and the application to anoxic limestone drain design. Appl Geochem http://dx.doi.org/ 10.1016/j.apgeochem.2007.10.004

ICDD (2002) Powder Diffraction File release 2002, PDF-2. International Centre for Diffraction Data, Newton Square

Kirby CS, Cravotta CA III (2005a) Net alkalinity and net acidity 1: Theoretical considerations. Appl Geochem 20:1920-1940

Kirby CS, Cravotta CA III (2005b) Net alkalinity and net acidity 2: Practical considerations. Appl Geochem 20:1941-1964

Kirby CS, Thomas HM, Southam G, Donald R (1999) Relative contributions of abiotic and biological factors in Fe(II) oxidation in mine drainage. Appl Geochem 14:511-530

Langmuir D (1997) Aqueous Environmental Geochemistry. PrenticeHall, NJ, USA, $600 \mathrm{pp}$

Morse JW (1983) The kinetics of calcium carbonate dissolution and precipitation. In: Reeder RJ (ed) Carbonates-mineralogy and chemistry. Mineral Soc America Rev Mineral 11:227-264

O’Neill BJ Jr (1964) Limestones and dolomites of Pennsylvania. Atlas of Pennsylvania's mineral resources, PA Geol Survey Mineral Resource Report 50, pp 1-40, map 9

Pennsylvania Dept of Environmental Protection (2000) Erosion and sediment pollution control program manual. PA DEP, Bureau of Watershed Mgmt, Doc \# 363-2134-008, tables 9 and 10A, Harrisburg, PA, USA, $180 \mathrm{pp}$

Plummer LN, Parkhurst DL, Wigley ML (1979) Critical review of the kinetics of calcite dissolution and precipitation. In: Jenne EA (ed) Chemical modeling in aqueous systems-speciation, sorption, solubility, and kinetics: American Chemical Society Symp Series 93, pp 537-573

PIRAMID Consortium (2003) Engineering guidelines for the passive remediation of acidic and/or metalliferous mine drainage and similar wastewaters. European Commission 5th Framework RTD Project \# EVK1-CT- 1999-000021, "Passive in-situ remediation of acidic mine/industrial drainage" (PIRAMID), Univ of Newcastle Upon Tyne, Newcastle Upon Tyne, UK, 166 pphttp://www.ncl.ac.uk/environment/research/documents/ PIRAMIDGuidelinesv1.0.pdf

Robbins EI, Nord GL, Savela CE, Eddy J, Livi KJT, Gullett CD, Nordstrom DK, Chou I-M, Briggs KM (1996) Microbial and mineralogical analysis of aluminum-rich precipitates that 
occlude porosity in a failed anoxic limestone drain, Monongalia County, West Virginia. In: Chiang S-H (ed) Proc 13th Annual International Pittsburgh Coal Conf, v 2. Reed \& Witting Co, Pittsburgh, pp 761-767

Robbins EI, Cravotta CA III, Savela CE, Nord GL Jr (1999) Hydrobiogeochemical interactions in "anoxic" limestone drains for neutralization of acidic mine drainage. Fuel 78:259-270

Santomartino S (2004) A laboratory study of limestone dissolution within passive limestone systems for treatment of acidic mine drainage and the implications of $\mathrm{Fe}$ precipitation on their longevity. LaTrobe Univ, Unpubl PhD thesis, $200 \mathrm{pp}$

Santomartino S, Webb JA (2007) Estimating the longevity of limestone drains in treating acid mine drainage containing high concentrations of iron. Appl Geochem 22:2344-2361

Schueck JH, Helfrich DR, Fromell DJ (2004) Limestone upflow pond with siphon discharge design considerations-a simple solution to high volume, high metals AMD discharges. Proc, $6^{\text {th }}$ Annual statewide conf on abandoned mine reclamation, Indiana, Western PA Coalition for Abandoned Mine Reclamation, Bedford, $23 \mathrm{pp}$

Skousen JG, Rose AW, Geidel G, Foreman J, Evans R, Hellier W (1998) Handbook of technologies for avoidance and remediation of acid mine drainage. National Mine Land Reclamation Center, Morgantown, $131 \mathrm{pp}$

Sterner PL, Skousen JJ, Donovan JJ (1998) Geochemistry of laboratory anoxic limestone drains. Proc, 1998 national meeting of the American Soc for Surface Mining and Reclamation, pp 214-234

Stumm W, Morgan JJ (1996) Aquatic chemistry-chemical equilibria and rates in natural waters. 3rd edn, Wiley Interscience, NY $1022 \mathrm{pp}$
Taggart JE Jr (2002) Analytical methods for chemical analysis of geologic and other materials, USGS Open-File Report 02-0223, http://pubs.usgs.gov/of/2002/ofr-02-0223/

Taylor JC, Clapp RA (1992) New features and advanced applications of Siroquant: A personal computer XRD full profile quantitative analysis software package. Adv X-ray Anal 35:49-55

Watzlaf GR (1997) Passive treatment of acid mine drainage in downflow limestone systems. Proc, 1997 national meeting of the American soc for surface mining and reclamation, May 10-15, 1997, Austin, American Soc for Surface Mining and Reclamation, pp 611-622

Watzlaf GR, Hedin RS (1993) A method for predicting the alkalinity generated by anoxic limestone drains. Proc, 14th annual meeting WV Surface Mine Drainage Task Force, WV Univ, Morgantown, WV, USA, $12 \mathrm{pp}$

Watzlaf GR, Schroeder KT, Kairies C (2000) Long-term performance of alkalinity-producing passive systems for the treatment of mine drainage. Proc, 2000 national meeting of the American Soc for Surface Mining and Reclamation, pp 262-274

Watzlaf GR, Schroeder KT, Kleinmann RLP, Kairies CL, Nairn RW (2004) The passive treatment of coal mine drainage. US DOE/ NETL-2004/1202http://www.netl.doe.gov/technologies/coalpower/ ewr/water/pdfs/Passive\%20Treatment.pdf

Weaver KR, Lagnese KM, Hedin RS (2004) Technology and design advances in passive treatment system flushing. Proc, 2004 national meeting of the American Soc for Surface Mining and Reclamation and the 25th west Virginia S, April 18-24, 2004, pp 1974-1989 